\title{
Article \\ An Analysis of Household Perceptions of Water Costs across the United States: A Survey Based Approach
}

\author{
Laura Medwid and Elizabeth A. Mack*
}

Citation: Medwid, L.; Mack, E.A. An Analysis of Household Perceptions of Water Costs across the United States: A Survey Based Approach. Water 2022, 14, 247. https://doi.org/ $10.3390 / w 14020247$

Academic Editor: Laura Bulgariu

Received: 6 December 2021

Accepted: 8 January 2022

Published: 15 January 2022

Publisher's Note: MDPI stays neutral with regard to jurisdictional claims in published maps and institutional affiliations.

Copyright: (C) 2022 by the authors. Licensee MDPI, Basel, Switzerland. This article is an open access article distributed under the terms and conditions of the Creative Commons Attribution (CC BY) license (https:// creativecommons.org/licenses/by/ $4.0 /)$.
Department of Geography, Environment, and Spatial Sciences, Michigan State University, 673 Auditorium Rd, East Lansing, MI 48824, USA; medwidla@msu.edu

* Correspondence: emack@msu.edu

\begin{abstract}
Research analyzing perceptions of water services has focused on water quality, water safety, and the propensity to consume water from different sources. It has not assessed perceptions of water costs. To address this knowledge gap, this study collected nationally representative survey data from households in the United States about water issues and incorporated these data into logistic regression models. In doing so, our study advances the water and public policy literature in three ways. One, it addresses the need for household resolution information about water issues given the absence of data at this scale in the United States. Two, it creates and utilizes one-of-a-kind survey data to understand the perceptions of household water bills and the drivers of these perceptions. Three, we assess the impact of proposed solutions to improve water affordability on household perceptions of water costs. Model results indicate low-income and households in underrepresented groups were more likely to perceive their water bills to be too high. The perception of water costs also varied geographically. From a policy perspective, model results indicate utilities can positively affect perceptions of water bills via the frequency of water billing and provision of payment assistance programs.
\end{abstract}

Keywords: water infrastructure; water services; water utilities; water bills; billing frequency; customer assistance programs (CAPS); affordability

\section{Introduction}

Approximately $68 \%$ of the world's population is projected to live in cities by 2050 , representing a 13\% increase in demand for water services in urban areas [1]. In addition to this rise in demand, water service providers face additional pressures related to institutional fragmentation, the inability to defray costs to replace deteriorating infrastructure, and increased capital costs to mitigate the impacts of climate change [2,3]. In the face of these challenges, urban water providers struggle to balance the rising costs of providing quality water service while simultaneously keeping the cost of service low for customers $[2,4,5]$.

In the United States, there is some indication individuals feel their water bills are too high. Anecdotal evidence from news stories cite a lack of billing transparency and a complex mesh of reasons for rising water costs from city to city [6-9]. In San Diego, CA for example, residents are confused about the sudden spike in water bills and meter readings, which they say cannot be explained by rate increases alone [7]. In Bayonne, New Jersey, the city cut a deal to have its water managed by a Wall Street firm that guarantees a rate of return on their investment, which has contributed to rising water costs for residents [9]. These consumer concerns and the rising cost of providing water services mean it is important to understand consumer perceptions of the cost of water services. To this point in time, research has not assessed perceptions of water costs. Instead, research has focused on analyzing perceptions of other aspects of water services including: water quality [10,11], water safety [12-16], and the propensity to consume water from different sources (e.g., tap water or bottled water) $[17,18]$. A Canadian study found for example that $72 \%$ of respondents in Toronto were 'somewhat' or 'extremely' concerned about chemical pollutants in the water [17]. 
A study of the state of Georgia, found that approximately half of the respondents rated drinking water quality as very safe, safe, or fair [19]. In a study within the state of Florida, respondents who had experienced water quality issues previously were more likely to perceive that water quality problems were becoming worse [18]. The same study also found that participation in extension programs improved the perceptions of water quality.

Studies also find that people's perceptions of quality are based on superficial characteristics or organoleptic properties (e.g., taste, hardness, color, odor) that do not pose health risks to people compared to invisible quality issues related to microbial or chemical contamination [12-14]. For instance, hardness of tap water was found to be a main reason individuals avoid consumption of tap water, despite the fact that hardness does not pose any health risk [14]. Studies of bottled water consumption also find a divergence or paradox between product characteristics and consumption preferences [20] that is tied to the perceptions of taste [21,22] and perceptions of water safety [23]. Research also points to perceptions of water safety as a reason that vulnerable populations, such as low-income households, females and racial/ethnic minorities are more likely to purchase bottled water $[19,22,24,25]$.

In terms of research that examines water costs directly, several studies have conducted research on water resource valuation, demand and willingness to pay [26,27]. Though the overall demand for water is inelastic [19], several trends have emerged in the literature. For instance, in Jordan and Elnagheeb's [19] study, Black Americans were willing to pay more for improvements in water quality than non-Black Americans. Willingness to pay was also found to increase with the level of education. Community engagement also affects public willingness to pay for watershed services as well as the level of public engagement in watershed management [28].

One of the largest disconnects between the perception of water costs and actual costs is access to clearly delineated water bills for household water consumers [26,29]. Interestingly, research indicates that the public's understanding of water rates is affected by the clarity of water bills [30]. Specifically, studies find that progressive price schedules are difficult to understand for consumers [30-32]. For example, a nation-wide study of the U.S. found that only $17 \%$ of utilities provided information about marginal prices and $78 \%$ provided no information other than the total amount required for payment [30]. More recent studies suggest this lack of clarity about water pricing may be linked to water consumption practices. For example, Binet et al. [33] investigated the perceived price of drinking-water when consumers are imperfectly informed about pricing schedules and found that households underestimate the price of water and consume more than what is economically rational. To this point in time, however, research on water and public policy has not yet evaluated the public's perception of the fairness of water costs.

To address this gap, this study designed and collected nationally representative survey data from over 9000 United States households about a variety of water issues, including the cost of water. These one-of-a-kind data were incorporated into logistic regression models to assess household perceptions of water bills and the characteristics of households who perceive their water bills to be too high. In doing so, our study advances the water and public policy literature by making several contributions. One, it addresses the need for household resolution information about water issues, given the lack of data at this scale in the United States. Two, it uses one of a kind survey data to understand the perceptions of household water bills and the drivers of these perceptions. Three, we assess the impact of proposed solutions to improve water affordability on household perceptions of water costs.

Model results indicate that low-income and racial/ethnic minority households were more likely to perceive their water bills to be too high. There are also geographic variations in household water perceptions that may reflect widespread affordability issues in particular parts of the country $[34,35]$. For example, respondents in the Detroit and Flint regions were the most likely to report their water bills are too high compared to other regions in the U.S. From a public policy perspective, model results suggest two ways that utilities and city governments can affect consumer perceptions of water prices. In particular, model results 
indicated that billing frequency and participation in payment assistance programs affects consumers' perceptions of whether water bills are too high. Compared to those billed monthly, households billed quarterly are more likely to say their water bills are too high. Yet, when extended to annual or semiannual billing, this trend reverses, and households are more likely to report their water bills are about right. These results indicate that monthly or annual billing may be ideal billing frequency options for utility companies. Participants enrolled in payment assistance programs were also less likely to perceive water bills were too high. This suggests the development of customer assistance programs (CAPs) could improve perceptions of the cost of water services.

\section{Materials and Methods}

To provide a first glance at perceptions of residential water costs across the United States, this study uses data from the Survey of Water Innovation and Socioeconomic Status of Households (SWISSH). This survey was designed by one of the authors to address the lack of household data in the United States about water issues and administered to a panel households by the Qualtrics survey firm [36]. The survey was administered to respondents at least 25 years of age in households across nine regions in the U.S. between December of 2017 and March of 2018. After data cleaning, 9250 responses were used in the analysis for this paper. These regions represent geographically, as well as socioeconomically and demographically diverse locations. Rim weights that combine race/ethnicity and income into one probability weight for each respondent are available so that the data are representative of households in the nine regions in terms of race/ethnicity and income, as indicated by 2011-2015 American Community Survey data from the U.S. Census Bureau [36].

The survey covers a variety of water issues, one question in particular asks respondents about their views on the amount of money they spend on water. The text of this question reads as follows: "In your opinion, is the amount you pay for water fair or unfair?" Respondents were given five response options to this question: (1) "unfair, the price of water should be higher", (2) "unfair, the price of water should be lower", (3) "fair, the price of water is about right", (4) "don't know", or (5) "prefer not to answer". Survey responses were coded with a " 1 " if consumers perceived them to be unfair and too high. The other responses were coded as a " 0 " if respondents indicated that the amount they pay for water is fair and about right or unfair because they were too low. Responses of "do not know" or "preferred not to answer" were excluded from our analysis.

Logistic regression models were estimated in STATA 14 [37] using the 'logit' command and were weighted with the 'svy' command. Rim weights were used to ensure representative samples that align with the demographic composition of the U.S. Census' American Community Survey. The probability that households report their water bills are too high is as follows:

$$
\operatorname{Pr}(\mathrm{y}=1 \mid \mathrm{x})=\mathrm{e}^{\mathrm{x}^{\prime} \beta} /\left(1+\mathrm{e}^{\mathrm{x}^{\prime} \beta}\right)
$$

where $y=1$ indicates water bills are too high. Vector $\beta$ consists of slope coefficients corresponding to the independent variables and an intercept. The overall predicted probability, $Y^{*}$ is a ratio between the probability that households feel their water bills are either too high or not too high, as shown in Equation (2).

$$
Y^{*}=\ln \left(\frac{P(\text { water cost too high })}{P(\text { water cost not too high })}\right)
$$

The base category (denominator) is any response in which households did not consider their water bills too high including a response of fair/about right, or unfair because they believe the cost could be higher. Vector $x$ in Equation (1) includes the exogenous variables chosen based on prior research associated with water quality and risk perceptions, willingness to pay for water, and awareness of environmental issues $[9,26]$. This body of work shows that demographic and socio-economic factors such as income, education, employment and race/ethnicity, are important to understanding perceptions of a range 
of water issues [23]. Independent variables in this model therefore include: (1) water bill characteristics such as water billing frequency and whether the household is enrolled in a water bill payment assistance plan, (2) socioeconomic characteristics including age and income, (3) demographic characteristics, (4) regional variables, and (5) other control variables. For example, we elected to include controls in the model, such as whether respondents have health insurance, because these factors may place them at financial risk. Therefore, health insurance status may affect their perceptions of financial issues, including the cost of water services. The complete list and description of variables are found in Table 1.

Table 1. Variable Names and Descriptions.

\begin{tabular}{|c|c|c|}
\hline Variable Name & Survey Question & Variable Description/Values \\
\hline Perception & $\begin{array}{l}\text { In your opinion, is the amount } \\
\text { you pay for water fair or unfair? }\end{array}$ & $\begin{array}{l}\text { Responses considered too high: } \\
\text { - Unfair, the price of water should be lower } \\
\text { Responses not considered too high: } \\
\text { - Fair, the price of water is about right } \\
\text { - } \quad \text { Unfair, the price of water should be higher }\end{array}$ \\
\hline Region & [Region based on zip code] & $\begin{array}{ll}\text { - } & \text { Eastern Massachusetts (Boston-Worcester) } \\
\text { - } & \text { Front Range-Colorado (Denver-Fort Collins) } \\
\text { - } & \text { Mid-Atlantic (Washington, DC-Baltimore, Maryland) } \\
\text { - } & \text { Piedmont Atlantic (Atlanta, Georgia-Charlotte, North Carolina) } \\
\text { - } & \text { Southeastern Florida (Miami-Palm Bay-Melbourne) } \\
\text { - } & \text { Southeastern Michigan (Detroit-Flint) } \\
\text { - } & \text { Southern California (Los Angeles-San Bernardino) } \\
\text { - } & \text { Sun Corridor-Arizona (Phoenix-Tucson) }\end{array}$ \\
\hline Wave & {$[\mathrm{N} / \mathrm{A}]$} & $\begin{array}{ll}- & \text { Wave } 1 \\
- & \text { Wave } 2 \\
- & \text { Wave } 3\end{array}$ \\
\hline Race & $\begin{array}{l}\text { With which racial or ethnic } \\
\text { group(s) do you identify } \\
\text { yourself? }\end{array}$ & $\begin{array}{ll}\text { - } & \text { Hispanic } \\
\text { - } & \text { Non-Hispanic African-American or Black } \\
\text { - } & \text { Non-Hispanic Asian or Asian-American } \\
\text { - } & \text { Middle Eastern, Native American or American Indian, Native } \\
& \text { Hawaiian or Pacific Islander, Other } \\
\text { - White } & \text { Whicion }\end{array}$ \\
\hline Age & In what year were you born? & [Age was calculated according to the year the survey was administered] \\
\hline Gender & Are you ... & $\begin{array}{ll}- & \text { Female } \\
-\quad & \text { Male }\end{array}$ \\
\hline Education & $\begin{array}{l}\text { What is the highest level of } \\
\text { school you have completed? }\end{array}$ & $\begin{array}{ll}\text { - } & \text { Did not finish high school } \\
\text { - } & \text { High school } \\
\text { - } & \text { Community college or vocational/technical school } \\
\text { - } & \text { 4-year college or graduate/professional degree }\end{array}$ \\
\hline Health Insurance & $\begin{array}{l}\text { Do you have health insurance? } \\
\text { Which of these types of } \\
\text { insurance do you have? }\end{array}$ & $\begin{array}{ll}\text { - } & \text { Medicaid } \\
\text { - } & \text { Medicare } \\
\text { - } & \text { No health insurance } \\
\text { - } & \text { Private health insurance }\end{array}$ \\
\hline
\end{tabular}


Table 1. Cont.

\begin{tabular}{|c|c|c|}
\hline Variable Name & Survey Question & Variable Description/Values \\
\hline $\begin{array}{l}\text { Assistance paying } \\
\text { water bill }\end{array}$ & $\begin{array}{l}\text { Do you participate in any } \\
\text { program that helps you pay } \\
\text { your water bill? }\end{array}$ & $\begin{array}{ll}- & \text { No } \\
- & \text { Yes }\end{array}$ \\
\hline Employment status & $\begin{array}{l}\text { Which of the following best } \\
\text { describes your current } \\
\text { employment or labor force } \\
\text { status? }\end{array}$ & $\begin{array}{ll}\text { - } & \text { Full-time/part-time } \\
\text { - } & \text { Unemployed/disability/not working/not looking } \\
\text { - } & \text { Retired } \\
\text { - } & \text { Student/homemaker/other }\end{array}$ \\
\hline Income & $\begin{array}{l}\text { What was the total combined } \\
\text { income before taxes of everyone } \\
\text { in your household in [year]? }\end{array}$ & $\begin{array}{ll}\text { - } & \text { Less than USD 50,000 } \\
\text { - } & \text { USD 50,000-USD 100,000 } \\
\text { - } & \text { More than USD 100,000 }\end{array}$ \\
\hline Household type & Do you live in ... & $\begin{array}{l}\text { - } \quad \text { A single-family home/townhouse/patio home } \\
\text { - } \quad \text { A multi-family home/apartment building } \\
\text { - } \quad \text { A mobile home or trailer } \\
\text { - } \quad \text { Other }\end{array}$ \\
\hline Frequency of water bill & $\begin{array}{c}\text { How is the water bill paid in } \\
\text { your household? }\end{array}$ & $\begin{array}{ll}\text { - } & \text { Monthly to the service provider } \\
\text { - } & \text { Quarterly to the service provider } \\
\text { - } & \text { Annually to the service provider } \\
\text { - } & \text { Water bill is covered by our rent } \\
\text { - } & \text { Water bill is covered by HOA/condo association } \\
\text { - } & \text { Have a well and do not pay service provider } \\
\text { - } & \text { Other }\end{array}$ \\
\hline
\end{tabular}

Note: response options in bold indicate the reference category for each variable.

Odds ratios are used to estimate the relative increase or decrease in the perception that water bills are too high associated with each explanatory variable. These odds ratios should be interpreted relative to reference groups for each variable, which are highlighted in bold in Table 1. In general, indicators of high socioeconomic status were selected as the base comparison category including those who are non-Hispanic White, earners over USD 100,000 , male, college graduate or higher, and full-time or part-time employment.

\section{Results}

A weighted tabulation and corresponding percentage of too high/other responses for select variables are presented in Table 2 which provides descriptive information about respondents. Tabulations and percentages were calculated for these variables because they are discrete and non-ordinal, and therefore, will be included as dummy variables in the regression analysis that follows. Most households (63.3\%) reported that their water bills were about right or should be higher. Approximately $36.7 \%$ reported their water bills were too high. Several demographic and socio-economic factors impacted the perceptions of water bills. Females were more likely to indicate their water bills were too high, as were racial/ethnic minorities. Blacks, Hispanics, and respondents identifying as some other race (e.g., Native American, Native Hawaiian or Pacific Islander, or Middle Eastern) were more likely to indicate their water bills were too high. People with lower levels of educational attainment were also more likely to report that their water bills were too high. In particular, people without a high school education were the most likely to report that their water bills were too high. Relatedly, people with incomes under USD 50,000 reported feeling water bills were too high. 
Table 2. Water Cost Perceptions and Household Demographic and Socio-Economic Characteristics.

\begin{tabular}{|c|c|c|c|c|c|c|}
\hline \multirow[t]{2}{*}{ Variable Category } & \multirow[t]{2}{*}{ Variable Option } & \multicolumn{2}{|c|}{ Fair/Should Be Higher } & \multicolumn{2}{|c|}{ Too High } & \multirow{2}{*}{ Total } \\
\hline & & $\#$ & $\%$ & $\#$ & $\%$ & \\
\hline \multicolumn{2}{|c|}{ TOO HIGH/OTHER } & 4147 & 63.3 & 2400 & 36.7 & 6611 \\
\hline \multirow{5}{*}{ RACE/ETHNICITY } & White & 2580 & 66.7 & 1291 & 33.3 & 3937 \\
\hline & Hispanic & 791 & 59.6 & 537 & 40.4 & 1387 \\
\hline & NH Black & 444 & 55.1 & 361 & 44.9 & 860 \\
\hline & NH Asian & 270 & 62.2 & 165 & 37.8 & 497 \\
\hline & Other & 63 & 56.9 & 47 & 43.1 & 167 \\
\hline \multirow{2}{*}{ GENDER } & Male & 1686 & 66.6 & 845 & 33.4 & 2598 \\
\hline & Female & 2452 & 61.3 & 1550 & 38.7 & 4064 \\
\hline \multirow{4}{*}{$\begin{array}{l}\text { HIGHEST LEVEL OF } \\
\text { EDUCATION }\end{array}$} & Bachelor's or Graduate Degree & 2548 & 67.0 & 1254 & 33.0 & 3870 \\
\hline & No High School & 54 & 50.0 & 54 & 50.0 & 159 \\
\hline & High School & 604 & 58.1 & 435 & 41.9 & 1097 \\
\hline & Community College & 929 & 58.3 & 664 & 41.7 & 1652 \\
\hline \multirow{3}{*}{ INCOME LEVEL } & $<50 \mathrm{k}$ & 1162 & 54.0 & 989 & 46.0 & 2206 \\
\hline & $50-100 \mathrm{k}$ & 1320 & 61.8 & 815 & 38.2 & 2198 \\
\hline & $>100 \mathrm{k}$ & 1664 & 73.6 & 596 & 26.4 & 2334 \\
\hline
\end{tabular}

Table 3 is similar in layout to Table 2 and presents additional information about other household characteristics including geographic location, employment status, and health insurance coverage according to water cost perception responses. The table also presents policy related information such as water bill frequency and respondents' enrollment in water payment programs. The table suggests there are regional differences in the percentage of respondents who felt their water bills were too high. The Pacific Northwest $(40.9 \%)$, Southeast Michigan (51.9\%), and Southern California (40.8\%) were regions where the largest proportion of individuals reported their water bills were too high. Regions where most respondents said their water bills were about right or too low are in the Piedmont Atlantic $(69.2 \%)$, the Mid-Atlantic (69.9\%), and the Sun Corridor (67.1\%). Some respondent and household characteristics had a much higher rate of reporting their water bills were too high. Some individuals reported their water bills were too high at a greater rate than the overall survey rate of $36.7 \%$ including those on Medicaid (49.0\%), with no health insurance $(46.5 \%)$, the unemployed (47.9\%), and living in a mobile home/trailer (47.3\%).

Table 4 presents the logistic regression results that help us understand which of the variables presented in Table 1 are explanatory variables of water bill perceptions, even after controlling for these factors simultaneously. Overall, income, geographic location, and race explained whether individuals considered their water bills to be too high. Compared to Whites, Black, Asian, and Hispanic individuals were more likely to perceive their water bill charges as too high: Hispanic respondents were $27.4 \%$ more likely to report water bills were too high, Black respondents were $43.8 \%$ more likely, and Asians were $32.1 \%$ more likely.

Income was also a strong indicator of whether respondents felt water bills were too high. Respondents in the lowest income bracket, making less than USD 50,000 per year were approximately 2.3 times more likely to report their water bills were too high compared to those making over USD 100,000 per year. Individuals in households making between USD 50,000 and USD 100,000 were approximately 75\% more likely to report their water bills were too high compared to those making over USD 100,000.

There were also statistically significant geographic trends in water bill perceptions. Compared to the Piedmont Atlantic region, four regions were statistically more likely to have respondents that perceived their water bills to be too high. In Eastern Massachusetts, respondents were $45.2 \%$ more likely to report water bills were too high. In Southern California, respondents were $63.8 \%$ more likely to indicate that water bills were too high In Southeast Michigan respondents were 2.59 times more likely to indicate they were billed 
too much for water, while in the Pacific Northwest, respondents were $70 \%$ more likely to indicate their water bills were too high. From a water provider perspective, two significant variables are particularly interesting. Billing frequency and enrollment in a water payment assistance program were significant explanatory factors behind perceptions of water bills. Households on a quarterly schedule for water bill payments were $18 \%$ more likely to consider their water bills to be too high. However, respondents indicating they paid their water bills annually or had their water included in their homeowners' association (HOA) fees were approximately half as likely to indicate they perceived their water bills as too high. Households enrolled in a payment assistance program were about $26 \%$ less likely to perceive their water bills to be too high.

Table 3. Water Cost Perceptions and Other Household Characteristics.

\begin{tabular}{|c|c|c|c|c|c|c|}
\hline \multirow[t]{2}{*}{ Variable Category } & \multirow[t]{2}{*}{ Variable Option } & \multicolumn{2}{|c|}{ Fair/Should Be Higher } & \multicolumn{2}{|c|}{ Too High } & \multirow{2}{*}{$\begin{array}{c}\text { Total } \\
\#\end{array}$} \\
\hline & & $\#$ & $\%$ & $\#$ & $\%$ & \\
\hline \multicolumn{2}{|c|}{ TOO HIGH/OTHER } & 4147 & 63.3 & 2400 & 36.7 & 6611 \\
\hline \multirow{9}{*}{ REGION } & Piedmont Atlantic & 580 & 69.2 & 258 & 30.8 & 907 \\
\hline & Mid-Atlantic & 488 & 69.9 & 210 & 30.1 & 768 \\
\hline & Eastern Massachusetts & 404 & 65.2 & 216 & 34.8 & 684 \\
\hline & Southeast Florida & 422 & 62.3 & 256 & 37.7 & 740 \\
\hline & Front Range & 517 & 68.9 & 234 & 31.1 & 819 \\
\hline & Southern California & 411 & 59.2 & 283 & 40.8 & 753 \\
\hline & Southeast Michigan & 352 & 48.1 & 379 & 51.9 & 779 \\
\hline & Pacific Northwest & 432 & 59.1 & 299 & 40.9 & 790 \\
\hline & Sun Corridor & 542 & 67.1 & 266 & 32.9 & 875 \\
\hline \multirow{3}{*}{ WAVE } & Wave 1 & 366 & 61.1 & 233 & 38.9 & 660 \\
\hline & Wave 2 & 1364 & 61.0 & 873 & 39.0 & 2298 \\
\hline & Wave 3 & 2417 & 65.1 & 1294 & 34.9 & 3777 \\
\hline \multirow{4}{*}{ HEALTH INSURANCE } & Private Health Insurance & 2503 & 64.9 & 1351 & 35.1 & 3919 \\
\hline & Medicaid & 280 & 51.0 & 270 & 49.0 & 601 \\
\hline & Medicare & 1015 & 66.9 & 502 & 33.1 & 1584 \\
\hline & None & 217 & 53.5 & 188 & 46.5 & 458 \\
\hline \multirow{2}{*}{$\begin{array}{c}\text { WATER PAYMENT } \\
\text { PROGRAM }\end{array}$} & Enrolled & 165 & 61.3 & 104 & 38.7 & 330 \\
\hline & Not Enrolled & 3970 & 63.4 & 2288 & 36.6 & 6321 \\
\hline \multirow{4}{*}{ EMPLOYMENT STATUS } & Full time/Part time & 2530 & 63.5 & 1453 & 36.5 & 4046 \\
\hline & $\begin{array}{l}\text { Unemployed/Not } \\
\text { Working/Looking }\end{array}$ & 233 & 52.1 & 214 & 47.9 & 500 \\
\hline & Retired & 1077 & 67.9 & 508 & 32.1 & 1653 \\
\hline & Student/Homemaker/Other & 300 & 57.7 & 220 & 42.3 & 578 \\
\hline \multirow{3}{*}{ HOUSEHOLD TYPE } & $\begin{array}{c}\text { Single Family } \\
\text { Home/Townhome }\end{array}$ & 3467 & 63.7 & 1976 & 36.3 & 5506 \\
\hline & $\begin{array}{c}\text { Multi-Family } \\
\text { Home/Apartment }\end{array}$ & 582 & 62.0 & 357 & 38.0 & 1001 \\
\hline & Mobile Home/Trailer & 56 & 52.7 & 50 & 47.3 & 158 \\
\hline \multirow{7}{*}{$\begin{array}{l}\text { WATER BILLING } \\
\text { FREQUENCY }\end{array}$} & Monthly & 2799 & 63.3 & 1626 & 36.7 & 4489 \\
\hline & Quarterly & 908 & 59.7 & 614 & 40.3 & 1582 \\
\hline & Annually/Semiannually & 71 & 75.0 & 24 & 25.0 & 170 \\
\hline & Bimonthly & 114 & 60.2 & 75 & 39.8 & 249 \\
\hline & $\mathrm{HOA} /$ Condo & 108 & 79.6 & 28 & 20.4 & 215 \\
\hline & Have Well & 115 & 95.5 & 5 & 4.5 & 215 \\
\hline & Other & 32 & 53.6 & 28 & 46.4 & 114 \\
\hline
\end{tabular}


Table 4. Logistic Regression Results: Odds Ratios for Factors affecting Perceptions of Water Bills.

\begin{tabular}{|c|c|c|c|c|}
\hline Variable Category & Base Variable & Variable Option & Odds Ratio & Standard Error \\
\hline \multirow{8}{*}{ REGION } & \multirow{8}{*}{ Piedmont Atlantic } & Mid-Atlantic & 1.112 & $(0.147)$ \\
\hline & & Eastern Massachusetts & $1.452^{* * *}$ & $(0.204)$ \\
\hline & & Southeast Florida & 1.207 & $(0.155)$ \\
\hline & & Front Range & 1.191 & $(0.149)$ \\
\hline & & Southern California & $1.638^{* * *}$ & $(0.212)$ \\
\hline & & Southeast Michigan & $2.588^{* * *}$ & $(0.330)$ \\
\hline & & Pacific Northwest & $1.704^{* * *}$ & $(0.206)$ \\
\hline & & Sun Corridor & 1.157 & $(0.143)$ \\
\hline \multirow{2}{*}{ WAVE } & \multirow{2}{*}{ Wave 1} & Wave 2 & 1.104 & $(0.130)$ \\
\hline & & Wave 3 & 0.974 & $(0.111)$ \\
\hline \multirow{4}{*}{ RACE/ETHNICITY } & \multirow{4}{*}{ White } & Hispanic & $1.274^{* * *}$ & $(0.119)$ \\
\hline & & NH Black & $1.438^{* * *}$ & $(0.136)$ \\
\hline & & NH Asian & $1.321^{* * *}$ & $(0.128)$ \\
\hline & & $\begin{array}{c}\text { NH Native American, Native } \\
\text { Hawaiian, Middle Eastern, } \\
\text { Other }\end{array}$ & 1.233 & $(0.191)$ \\
\hline GENDER & Male & Female & 1.063 & $(0.069)$ \\
\hline $\begin{array}{l}\text { HIGHEST LEVEL OF } \\
\text { EDUCATION }\end{array}$ & $\begin{array}{l}\text { Bachelor's or Graduate } \\
\text { Degree }\end{array}$ & $\begin{array}{l}\text { No High School } \\
\text { High School } \\
\text { Community College }\end{array}$ & $\begin{array}{l}0.719 \\
1.006 \\
1.067\end{array}$ & $\begin{array}{l}(0.207) \\
(0.093) \\
(0.081)\end{array}$ \\
\hline HEALTH INSURANCE & Private Health Insurance & $\begin{array}{l}\text { Medicaid } \\
\text { Medicare } \\
\text { None }\end{array}$ & $\begin{array}{c}1.131 \\
0.826^{* *} \\
1.162\end{array}$ & $\begin{array}{l}(0.134) \\
(0.078) \\
(0.157)\end{array}$ \\
\hline SOCIAL PROGRAM & $\begin{array}{l}\text { Enrolled in Water Bill } \\
\text { Payment Program }\end{array}$ & $\begin{array}{c}\text { Note enrolled in water bill } \\
\text { payment program }\end{array}$ & $0.738^{* *}$ & $(0.114)$ \\
\hline $\begin{array}{l}\text { EMPLOYMENT } \\
\text { STATUS }\end{array}$ & Full Time/Part Time & $\begin{array}{l}\text { Unemployed/Disability/Not } \\
\text { Working and Not Looking } \\
\text { Retired } \\
\text { Student/Homemaker/Other }\end{array}$ & $\begin{array}{c}1.121 \\
0.842 * \\
1.213\end{array}$ & $\begin{array}{l}(0.085) \\
(0.145) \\
\end{array}$ \\
\hline INCOME LEVEL & $>100 \mathrm{k}$ & $\begin{array}{c}<50 \mathrm{k} \\
50-100 \mathrm{k}\end{array}$ & $\begin{array}{l}2.343^{* * *} \\
1.745^{* * *}\end{array}$ & $\begin{array}{l}(0.217) \\
(0.131)\end{array}$ \\
\hline HOUSEHOLD TYPE & $\begin{array}{c}\text { Single family } \\
\text { home/townhome }\end{array}$ & $\begin{array}{c}\text { Multi-Family } \\
\text { Home/Apartment } \\
\text { Mobile Home/Trailer }\end{array}$ & $\begin{array}{l}0.943 \\
1.175\end{array}$ & $\begin{array}{l}(0.086) \\
(0.314)\end{array}$ \\
\hline $\begin{array}{l}\text { WATER BILLING } \\
\text { FREQUENCY }\end{array}$ & Monthly & $\begin{array}{c}\text { Quarterly } \\
\text { Annually/Semiannually } \\
\text { Bimonthly } \\
\text { HOA/Condo } \\
\text { Have Well } \\
\text { Other }\end{array}$ & $\begin{array}{l}1.182^{* *} \\
0.504^{* *} \\
1.107 \\
0.508^{* * *} \\
0.089^{* * *} \\
1.289\end{array}$ & $\begin{array}{l}(0.100) \\
(0.147) \\
(0.191) \\
(0.133) \\
(0.039) \\
(0.368)\end{array}$ \\
\hline AGE & $\mathrm{N} / \mathrm{A}$ & Age & $1.009^{* * *}$ & $(0.003)$ \\
\hline CONSTANT & & Constant & $0.148^{* * *}$ & $(0.032)$ \\
\hline
\end{tabular}

Note: ${ }^{*} p<0.1 ;{ }^{* *} p<0.05 ;{ }^{* * *} p<0.01 . \mathrm{N}=6198$ F-statistic $=9.305^{* * *}$.

Table 5 presents information from the U.S. Census Bureau and the Environmental Protection Agency's Environmental Quality Index (EQI) [38] for each of the regions to provide context to the regression results. These data correspond to the counties containing the city pairs of interest in each region, as listed earlier in Table 1. Social and demographic 
information comes from the U.S. Census Bureau's American Community Survey 20152019 [39]. The EQI index presents a county-level ranking of overall environmental quality according to five categories: air, water, land, built, and sociodemographic environments across the U.S [38]. Table 5 includes a measure of the total overall ranking, as well as the water subset of the EQI. Low rankings represent lower levels of degradation. The rankings are based on percentiles across U.S. counties as follows: lowest (0-5th percentile); very low (5th-20th percentile); low (20th-40th percentile); moderate (40th-60th percentile); high (60th-80th percentile); very high (80th-95th percentile); highest (95th-100 percentile). In Table 5, the regions are divided into two groups according to the previous regression results: regions where respondents were less likely to perceive their water bills to be too high and regions that were more likely to perceive their water bills to be too high.

The regions more likely to say their water bills are too high have on average, a higher percentage of individuals with a high school education or below (38.24\% compared to $31.3 \%$ ), a higher non-White population (43\% compared to $30 \%$ ), and higher population densities. Median household income and poverty levels were similar for both. Regions with a higher percentage of households more likely to say their water bills are too high are located in counties with a ranking of water quality problems ranging from high to highest ( $75 \%$ for regions more likely to report bills too high compared to $50 \%$ for those less likely). These regions also have higher levels of environmental degradation (37.5\% compared to $30 \%)$. Therefore, respondents from regions that perceived their water bills to be too high are more likely to live in areas of lower water and lower environmental quality.

Table 6 presents tabulations of survey questions for respondents who felt their water bills were too high, which provide important contextual information about respondents' experiences with water and utilities (e.g., water and electricity). Based on the information presented in this table, the majority of households who perceive their water bills to be too high worry about the cost of water and are less likely to feel they can easily afford their water bills. Only $44.7 \%$ of these households reported they could easily afford their water bills and $81.2 \%$ say they worry about the cost of water. However, a lower percentage of these same respondents have had prior experience with utility affordability issues. Of the respondents who indicated their water bills were too high, just over a third had experienced prior restrictions on water use $(32.8 \%)$ or had received a water $(32.2 \%)$ or electric shutoff notification (36.3\%);23.3 percent and 20.5 percent had experienced a water or electric shutoff respectively.

Interestingly, these views and experiences do not appear to have impacted respondents' trust in public institutions at the time of the survey. Table 7 presents tabulations of survey questions about trust in public institutions, which may be a driver of water bill perceptions; households with low trust in institutions may be more likely to perceive water bills to be too high. The table indicates however, that the majority of respondents felt confident in institutions such as their local water utility (62\%), flood control district (54.6\%) and public health agencies $(58.5 \%)$. A somewhat lower percentage of respondents felt confident about their city/town government (50.6\%). 
Table 5. Study Region Social, Economic, and Environmental Quality Characteristics.

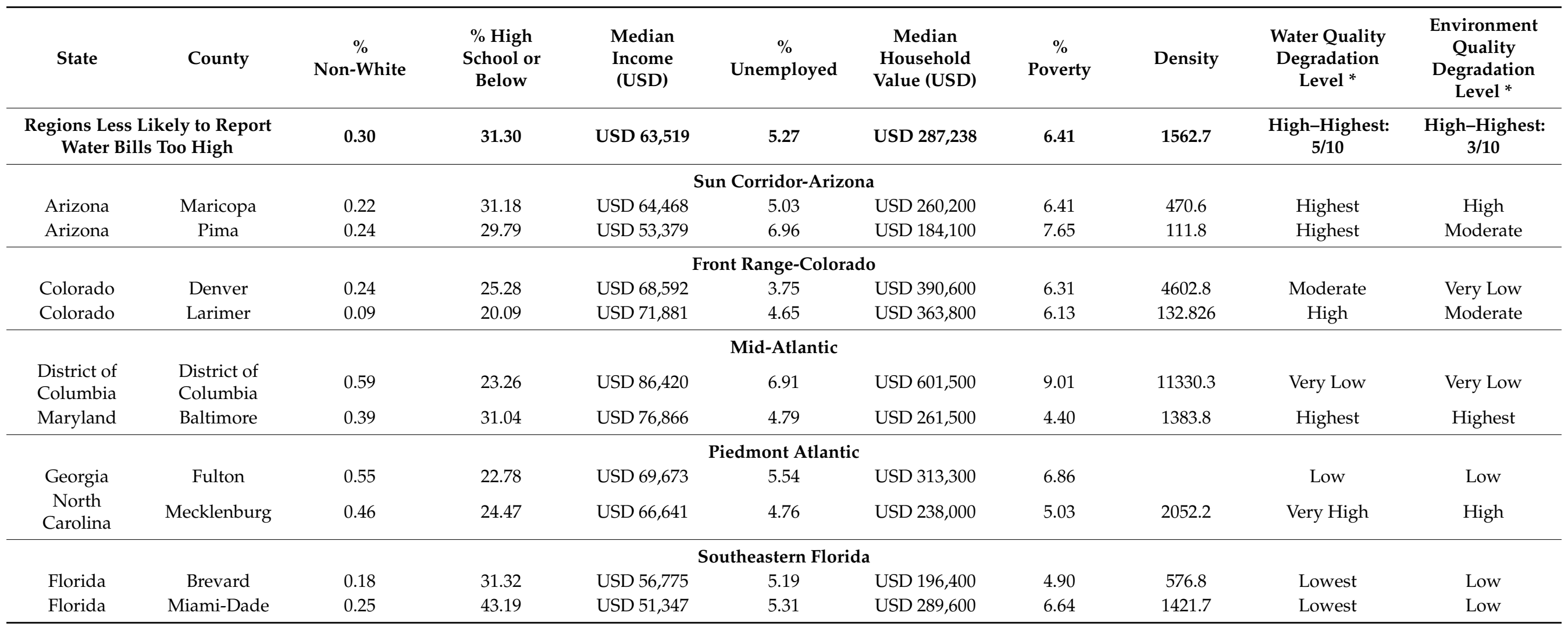


Table 5. Cont.

\begin{tabular}{|c|c|c|c|c|c|c|c|c|c|c|}
\hline State & County & $\begin{array}{c}\% \\
\text { Non-White }\end{array}$ & $\begin{array}{l}\text { \% High } \\
\text { School or } \\
\text { Below }\end{array}$ & $\begin{array}{l}\text { Median } \\
\text { Income } \\
\text { (USD) }\end{array}$ & $\begin{array}{c}\% \\
\text { Unemployed }\end{array}$ & $\begin{array}{c}\text { Median } \\
\text { Household } \\
\text { Value (USD) }\end{array}$ & $\begin{array}{c}\% \\
\text { Poverty }\end{array}$ & Density & $\begin{array}{l}\text { Water Quality } \\
\text { Degradation } \\
\text { Level * }\end{array}$ & $\begin{array}{c}\text { Environment } \\
\text { Quality } \\
\text { Degradation } \\
\text { Level * }\end{array}$ \\
\hline \multicolumn{2}{|c|}{$\begin{array}{l}\text { Regions More Likely to Report } \\
\text { Water Bills Too High }\end{array}$} & 0.43 & 38.24 & USD 64,985 & 6.60 & USD 457,382 & 6.93 & 2527.5 & $\begin{array}{l}\text { High-Highest: } \\
6 / 8\end{array}$ & $\begin{array}{l}\text { High-Highest: } \\
\quad 3 / 8\end{array}$ \\
\hline \multicolumn{11}{|c|}{ Eastern Massachusetts } \\
\hline Massachusetts & Suffolk & 0.45 & 32.85 & USD 69,669 & 6.39 & USD 496,500 & 8.95 & 13676.7 & Very Low & Moderate \\
\hline Massachusetts & Worcester & 0.16 & 33.54 & USD 74,679 & 5.00 & USD 280,600 & 4.75 & 546.0 & Very High & Highest \\
\hline \multicolumn{11}{|c|}{ Southeastern Michigan } \\
\hline Michigan & Genesee & 0.25 & 36.75 & USD 48,588 & 9.33 & USD 111,100 & 8.36 & 640.3 & Moderate & Low \\
\hline Michigan & Wayne & 0.47 & 38.67 & USD 47,301 & 9.20 & USD 113,000 & 10.43 & 2871.4 & High & Very High \\
\hline \multicolumn{11}{|c|}{ Pacific Northwest } \\
\hline Oregon & Lane & 0.13 & 26.95 & USD 52,426 & 6.90 & USD 263,200 & 8.30 & 81.9 & Very High & Low \\
\hline Oregon & Multnomah & 0.22 & 22.02 & USD 69,176 & 4.93 & USD 386,200 & 6.34 & 1866.4 & Very High & Low \\
\hline \multicolumn{11}{|c|}{ Southern California } \\
\hline California & $\begin{array}{c}\text { San } \\
\text { Bernardino }\end{array}$ & 0.39 & 43.20 & USD 63,362 & 7.66 & USD 328,200 & 7.01 & 107.1 & Highest & High \\
\hline
\end{tabular}

Note: Data sources: U.S. Census Bureau 2015-2019 County Level Estimates [39] and the U.S. Environmental Protection Agency's Environmental Quality Index [38]. 
Table 6. Contextual Survey Questions Related to Experiences with Water Services.

\begin{tabular}{|c|c|c|c|c|}
\hline Question & Variable Option & Response Options & \# & $\%$ \\
\hline \multirow{15}{*}{$\begin{array}{c}\text { In the Past } 12 \\
\text { Months Have You } \\
\text { Had ... }\end{array}$} & \multirow{3}{*}{$\begin{array}{l}\text { Water Use } \\
\text { Restriction }\end{array}$} & Yes & 443 & 32.8 \\
\hline & & No & 909 & 67.2 \\
\hline & & Total & 1353 & 100.0 \\
\hline & \multirow{3}{*}{$\begin{array}{c}\text { Water Shutoff } \\
\text { Notification }\end{array}$} & Yes & 180 & 32.2 \\
\hline & & No & 378 & 67.8 \\
\hline & & Total & 558 & 100.0 \\
\hline & \multirow{3}{*}{ Water Shutoff } & Yes & 94 & 23.3 \\
\hline & & No & 311 & 76.7 \\
\hline & & Total & 405 & 100.0 \\
\hline & \multirow{3}{*}{$\begin{array}{l}\text { Electric Shutoff } \\
\text { Notification }\end{array}$} & Yes & 248 & 36.3 \\
\hline & & No & 435 & 63.7 \\
\hline & & Total & 683 & 100.0 \\
\hline & \multirow{3}{*}{ Electric Shutoff } & Yes & 98 & 20.5 \\
\hline & & No & 381 & 79.5 \\
\hline & & Total & 480 & 100.0 \\
\hline \multirow{16}{*}{$\begin{array}{l}\text { Do you agree or } \\
\text { disagree with the } \\
\text { following } \\
\text { statements? }\end{array}$} & \multirow{4}{*}{$\begin{array}{l}\text { Cost of Water } \\
\text { has Increased }\end{array}$} & Disagree & 127 & 5.3 \\
\hline & & Neither agree nor disagree & 439 & 18.4 \\
\hline & & Agree & 1822 & 76.3 \\
\hline & & Total & 2388 & 100.0 \\
\hline & \multirow{4}{*}{$\begin{array}{c}\text { Easily Afford my } \\
\text { Water Bill }\end{array}$} & Disagree & 635 & 26.5 \\
\hline & & Neither agree nor disagree & 689 & 28.8 \\
\hline & & Agree & 1068 & 44.7 \\
\hline & & Total & 2392 & 100.0 \\
\hline & \multirow{4}{*}{$\begin{array}{l}\text { Worried about } \\
\text { Cost of Water }\end{array}$} & Disagree & 149 & 6.2 \\
\hline & & Neither agree nor disagree & 301 & 12.6 \\
\hline & & Agree & 1939 & 81.2 \\
\hline & & Total & 2388 & 100.0 \\
\hline & \multirow{4}{*}{$\begin{array}{l}\text { I Conserve Water } \\
\text { Due to Expense }\end{array}$} & Disagree & 212 & 8.9 \\
\hline & & Neither agree nor disagree & 377 & 15.8 \\
\hline & & Agree & 1802 & 75.4 \\
\hline & & Total & 2392 & 100.0 \\
\hline
\end{tabular}

Note: Affirmative responses (yes or agree) are presented in bold in this table.

Table 7. Survey Questions Related to Trust in Institutions.

\begin{tabular}{ccccc}
\hline Question & Variable Option & Response Options & $\#$ & \% \\
\hline & Your Local Water & Not Confident & 381 & 16.4 \\
& Utility & Neutral & 503 & 21.6 \\
& & Confident & 1444 & 62.0 \\
& & Total & 2329 & 100.0 \\
\cline { 2 - 5 } As far as these institutions & City/Town & Not Confident & 537 & 23.0 \\
and their leaders are & Government & Neutral & 614 & 26.3 \\
concerned, how confident & & Confident & 1181 & 50.6 \\
are you in each of the & & Total & 2333 & 100.0 \\
\cline { 2 - 5 } following? & Your & Not Confident & 337 & 15.8 \\
& Drainage/Flood & Neutral & 635 & 29.7 \\
& Control District & Confident & 1167 & 54.6 \\
& & Total & 2139 & 100.0 \\
\cline { 2 - 5 } & & Not Confident & 395 & 17.2 \\
& Public Health & Neutral & 562 & 24.4
\end{tabular}




\section{Discussion}

The United States is in an era of infrastructure replacement, which will require massive investments totaling an estimated USD 600 billion towards water infrastructure over the next two decades [3]. These investments, along with shutoffs in water service in several cities across the United States and the Flint water crisis, suggest that trust in water service and also the perceptions of water services are important to analyze at this juncture in history. Aside from consumer reactions to water costs, the perceptions of these costs are also important for water utilities to bear in mind since a sizable customer base that considers water bills to be too high may lead to the inability or unwillingness to pay for water services. It may also cause consumers to switch to alternate water sources, such as private wells or bottled water, which could erode the revenue streams of utilities [40]. Combined, these coping strategies may erode the long-term customer base of utilities and public engagement in local water policy decisions [41]. To this point in time, however, studies of water perceptions in the developed world have assessed dimensions of water services (e.g., quality and willingness to pay) other than perceptions of water costs. To address this research gap, the goal of this paper was to analyze the perceptions of households regarding the cost of water services and to assess the characteristics of households who felt their water bills were too high.

Not surprisingly, income was one of the more important factors in explaining water bill perceptions. Households making less than USD 50,000 were more likely to feel that their water bills were too high. Even after controlling for income, race was also a significant factor behind households' perceptions of water bills. Non-white, minority households were more likely to perceive that their water bills were too high. This finding is in line with recent research, which finds high water costs disproportionately affect communities of color $[42,43]$. Studies suggest that these high costs are a result of population decline in urban areas and postindustrial divestment [42]. It may also reflect the fact that Black and Hispanic neighborhoods are at higher risk for water shutoffs due to non-payment than predominantly White neighborhoods [29].

Another important finding of this study was variations in household perceptions across particular regions of the country. Households in four regions of the country (e.g., Eastern Massachusetts, Southern California, Southeast Michigan, and Pacific Northwest) were more likely to perceive water bills as being too high. This may reflect the higher cost of living in three of these areas of the country (Eastern Massachusetts, Southern California, Pacific Northwest). In Southeast Michigan, which includes the cities of Flint and Detroit, these results may reflect consumer awareness of shutoffs in Detroit and also rising water rates in these cities [34,35].

Model results also indicated that the frequency of billing affects perceptions of water bills. Respondents billed quarterly were more likely to consider their water bills to be too high compared to customers billed monthly or annually. Therefore, one recommendation based on these findings is for water companies to bill monthly, which prior work indicates helps household budget their money better [44]. Alternatively, companies could also bill households annually, allowing for customers to easily anticipate this one-time annual payment without focusing on water costs for the rest of the year. Another important result was that water payment programs reduced the likelihood that households perceived their water bills to be too high. This finding suggests that water providers should work to establish water assistance programs for customers in need. At present there is no federal framework guiding the implementation of customer assistance programs (CAPs) [45], which provides utilities with a good deal of flexibility in structuring these programs. Types of CAPs that may be offered range from water efficiency programs to bill discounts to lifeline rates [46]. Important considerations in CAP design that influence program cost include the program size and the type of assistance offered [46]. State laws governing utility regulation and the wording and interpretation of state statutes are also important considerations to keep in mind when designing programs because the legal barriers to CAPs do vary across states and utility type [8]. If a utility already has a CAP in place, 
providers may want to develop outreach programs to communicate with customers and enhance their awareness of CAPS.

That said, it is important to acknowledge some limitations of the present study. One, the SWISSH survey contains several questions that ask about pollution in nearby water bodies and experiences with water pollution. These questions were not incorporated into the logit model because pollution is not related to the primary topic of this paper. In addition, as noted previously in the introduction to this paper, research on public perceptions of the quality of local water resources finds that perceptions of the quality of local water resources are based predominantly on organoleptic properties such as taste and turbidity, which are not based on measurable safety or water quality metrics $[23,47]$. Studies also show the perceived risk of local water resources is strongly associated with perceived (not necessarily measurable levels) of chemicals in water, external information, past health problems, and trust in water suppliers [47]. Two, the SWISSH survey does ask respondents to estimate the amount of their last water bill. We elected not to include this information in the models because prior research has indicted that biases in responses are likely to arise related to recall problems [48]. Studies have also found that consumers do not have an accurate understanding about how their water bills are calculated or how much they pay for water services [30]. There is also no nationwide data available in the United States about water rates to use in place of survey data. The American Water Works Association (AWWA) has a survey, but it is only for AWWA member utilities and is not representative of all utilities across the nation. The University of North Carolina also provides some rate data [49], but the coverage of these data is not national. It is also prohibitive from a time and financial perspective to collect rate data for the nation as a whole. Collecting this information would require collaboration with thousands of water providers. Harmonizing these data would also be quite complex because utilities use different pricing strategies for water in the United States, which contributes further to the infeasibility of creating a nationwide water rate database. A third limitation of this study is that it does not control for household water use, which could impact the amount of water bills and also perceptions of water bills. To control for this, water usage data would need to be acquired from individual utilities which may be infeasible because of privacy concerns for customers. It is also not feasible to acquire usage data with the same coverage as the SWISSH survey.

The limitations of this paper present several opportunities for future research that expand on the present study. One, future work could collect information about water costs, water use, and survey data about perceptions of water costs, based on those provided by the SWISSH survey, to understand the linkages between water cost, water use, and perceptions of water costs. Acquiring these data would also require the cooperation of a utility and would require them to solicit information from customers. There may be privacy risks to customers in acquiring these data, however. Thus, the feasibility of this research path is questionable. Two, future work could collect information about actual water costs from customer bills, and pair these data with survey data from customers about their estimated costs of water. This would be useful in understanding the extent customers are aware of the actual cost of their water use and their recall accuracy. Again, the privacy risk to customers and the time burden this may place on utilities may render this research path unfeasible. Third, the results of our study suggest that news coverage about water issues may explain geographic differences in household perceptions of water costs, particularly in Southeast Michigan, that includes the cities of Flint and Detroit, which has received a lot of national news coverage related to water shutoffs and water rate increases [34,35]. Future work could test the extent that news coverage creates bias in household perceptions of water costs by collecting times series information about water rates from individual providers, survey data about customer perceptions of water trends and news reports from the media about water issues. This type of survey design has fewer data privacy risks for individual consumers, but is risky because the data collection would be time intensive and require a knowledgeable team of personnel which could also be quite costly. 


\section{Conclusions}

This study provided the first examination of household perceptions of water costs across nine geographically, demographically, and socioeconomically diverse regions of the United States. In doing so, our study advances the water and public policy literature in three ways. One, it collected one-of-a-kind survey data to address the need for household resolution information about water issues given the absence of data at this scale in the United States. Two, it incorporated these one-of-a-kind survey data into logistic regression models to understand the drivers of household perceptions of water costs. Three, we assessed the impact of proposed solutions to improve water affordability on household perceptions of water costs. Model results indicated low-income and households in underrepresented groups, such as racial and ethnic minorities, were more likely to perceive their water bills to be too high. The perception of water costs also varied geographically. From a policy perspective, model results indicate utilities can positively affect perceptions of water bills via the frequency of water billing and provision of payment assistance programs. Utilities could also use the information from the survey and model results to focus outreach and communication activities to customers who feel their water bills are too high. As water utilities and city governments navigate the conflicting objectives of maintaining and upgrading water systems at prices that are affordable for a majority of water users, communication with customers will be key to maintaining good relationships during this period of change and adaptation.

Author Contributions: Conceptualization, L.M. and E.A.M.; methodology, L.M.; formal analysis, L.M.; resources, E.A.M.; data curation, L.M.; writing-original draft preparation, L.M. and E.A.M.; writing—review and editing, L.M. and E.A.M.; supervision, E.A.M.; project administration, E.A.M.; funding acquisition, E.A.M. All authors have read and agreed to the published version of the manuscript.

Funding: This research was funded by National Science Foundation Grant Number 1444758 and Supplement Number 1444758. The APC was funded by Michigan State University's Department of Geography, the Environment and Spatial Sciences and Laura Medwid.

Institutional Review Board Statement: The study was approved and deemed exempt in accordance with federal regulations by the Institutional Review Board (IRB) of Michigan State University (IRB\# x16-579e 16 April 2016) for studies involving human subjects.

Informed Consent Statement: Informed consent was obtained from all subjects involved in the study.

Data Availability Statement: Data for this study may be accessed via the Harvard Dataverse https: / / doi.org/10.7910/DVN/0ETQ74 (accessed on 24 June 2021).

Conflicts of Interest: The authors declare no conflict of interest. The funders had no role in the design of the study; in the collection, analyses, or interpretation of data; in the writing of the manuscript, or in the decision to publish the results.

\section{References}

1. United Nations (U.N.). 68\% of the World Population Projected to Live in Urban Areas by 2050, Says N. Department of Economic and Social Affairs 2018. Available online: https://www.un.org/development/desa/en/news/population/2018-revision-ofworld-urbanization-prospects.html (accessed on 24 June 2021).

2. Scott, T.A.; Moldogaziev, T.; Greer, R.A. Drink What You Can Pay for: Financing Infrastructure in a Fragmented Water System. Urban Stud. 2018, 55, 2821-2837. [CrossRef]

3. U.S. Environmental Protection Agency (EPA). About the Water Infrastructure and Resiliency Finance Center. 2016. Available online: https:/ /19january2017snapshot.epa.gov/waterfinancecenter/about-water-infrastructure-and-resiliency-finance-center_ .html (accessed on 20 June 2021).

4. Sik Lee, K.; Anas, A.; Oh, G.-T. Costs of Infrastructure Deficiencies for Manufacturing in Nigerian, Indonesian and Thai Cities. Urban Stud. 1999, 36, 2135-2149. [CrossRef]

5. Wu, X.; Malaluan, N.A. A Tale of Two Concessionaires: A Natural Experiment of Water Privatisation in Metro Manila. Urban Stud. 2008, 45, 207-229. [CrossRef] 
6. Adams, J. Jackson Residents Concerned about Overpriced Water Bills after Water Crisis. ABC—WAPT News. 2018. Available online: https:/ / www.wapt.com/article/jackson-residents-concerned-about-overpriced-water-bills-after-water-crisis/35771244 (accessed on 10 March 2021).

7. DiBono, M. North County Residents Frustrated by Spike in Water Bills. Fox5 San Diego. Available online: https://fox5sandiego. com/news/local-news/north-county-residents-frustrated-by-spike-in-water-bills/ (accessed on 6 June 2021).

8. Davis, E. You Paid for It: Bunker Hill Residents Boiling Mad over High Water Bills. Fox2 Now. 2021. Available online: https: //fox2now.com/news/you-paid-for-it/you-paid-for-it-bunker-hill-residents-boiling-mad-over-high-water-bills/ (accessed on 3 October 2021).

9. Ivory, D.; Protess, B.; Palmer, G. In American Towns, Private Profits from Public Works. The New York Times. Available online: https:/ / www.nytimes.com/2016/12/24/business/dealbook/private-equity-water.html (accessed on 3 October 2021).

10. Dolnicar, S.; Schäfer, A.I. Desalinated versus Recycled Water: Public Perceptions and Profiles of the Accepters. J. Environ. Manag. 2009, 90, 888-900. [CrossRef] [PubMed]

11. Martinez-Espineira, R.; García-Valiñas, M.A.; González-Gómez, F. Does Private Management of Water Supply Services Really Increase Prices? An Empirical Analysis in Spain. Urban Stud. 2009, 46, 923-945. [CrossRef]

12. Jones, A.Q.; Dewey, C.E.; Doré, K.; Majowicz, S.E.; McEwen, S.A.; Waltner-Toews, D.; Henson, S.J.; Mathews, E. A Qualitative Exploration of the Public Perception of Municipal Drinking Water. Water Policy 2007, 9, 425-438. [CrossRef]

13. Wright, J.A.; Yang, H.; Rivett, U.; Gundry, S.W. Public Perception of Drinking Water Safety in South Africa 2002-2009: A Repeated Cross-Sectional Study. BMC Public Health 2012, 12, 556. [CrossRef]

14. Celik, E.; Muhammetoglu, H. Improving Public Perception of Tap Water in Antalya City, Turkey. J. Water Supply Res. Technol.AQUA 2008, 57, 109-113. [CrossRef]

15. Levêque, J.G.; Burns, R.C. A Structural Equation Modeling Approach to Water Quality Perceptions. J. Environ. Manag. 2017, 197, 440-447. [CrossRef]

16. Wang, Q.; Shaheen, S.M.; Jiang, Y.; Li, R.; Slaný, M.; Abdelrahman, H.; Kwon, E.; Bolan, N.; Rinklebe, J.; Zhang, Z. Fe/Mn-and P-Modified Drinking Water Treatment Residuals Reduced $\mathrm{Cu}$ and Pb Phytoavailability and Uptake in a Mining Soil. J. Hazard. Mater. 2021, 403, 123628. [CrossRef]

17. Auslander, B.A.; Langlois, P.H. Toronto Tap Water: Perception of Its Quality and Use of Alternatives. Can. J. Public Health/Rev. Can. De Sante Publique 1993, 84, 99-102.

18. Huang, P.; Lamm, A.J. Impact of Experience and Participation in Extension Programming on Perceptions of Water Quality Issues. J. Int. Agric. Ext. Educ. 2015, 22, 35-49. [CrossRef]

19. Jordan, J.L.; Elnagheeb, A.H. Willingness to Pay for Improvements in Drinking Water Quality. Water Resour. Res. 1993, 29, 237-245. [CrossRef]

20. Debbeler, L.J.; Gamp, M.; Blumenschein, M.; Keim, D.; Renner, B. Polarized but Illusory Beliefs about Tap and Bottled Water: A Product-and Consumer-Oriented Survey and Blind Tasting Experiment. Sci. Total Environ. 2018, 643, 1400-1410. [CrossRef]

21. Levallois, P.; Grondin, J.; Gingras, S. Evaluation of Consumer Attitudes on Taste and Tap Water Alternatives in Quebec. Water Sci. Technol. 1999, 40, 135-139. [CrossRef]

22. Saylor, A.M. What's Wrong with the Tap? Why Purdue University Students, Faculty, and Staff Are Choosing Bottled Water. Master's Thesis, Purdue University, West Lafayette, IN, USA, 2010.

23. Hu, Z.; Morton, L.W.; Mahler, R.L. Bottled Water: United States Consumers and Their Perceptions of Water Quality. Int. J. Environ. Res. Public Health 2011, 8, 565-578. [CrossRef]

24. Merkel, L.; Bicking, C.; Sekhar, D. Parents' Perceptions of Water Safety and Quality. J. Community Health 2012, 37, 195-201. [CrossRef]

25. Moore, P. Poll Results: Water Contamination. YouGov. Available online: https://today.yougov.com/topics/politics/articlesreports/2016/03/16/poll-results-water-contamination (accessed on 8 April 2021).

26. Arbues, F.; Villanua, I. Potential for Pricing Policies in Water Resource Management: Estimation of Urban Residential Water Demand in Zaragoza, Spain. Urban Stud. 2006, 43, 2421-2442. [CrossRef]

27. García-Rubio, M.A.; Ruiz-Villaverde, A.; González-Gómez, F. Urban Water Tariffs in Spain: What Needs to Be Done? Water 2015, 7, 1456-1479. [CrossRef]

28. Kosoy, N.; Martinez-Tuna, M.; Muradian, R.; Martinez-Alier, J. Payments for Environmental Services in Watersheds: Insights from a Comparative Study of Three Cases in Central America. Ecol. Econ. 2007, 61, 446-455. [CrossRef]

29. Walton, B. Water Affordability Is a New Civil Rights Movement in the United States. Circle of Blue. 2016. Available online: https:/ / www.circleofblue.org/2016/water-policy-politics/water-rights-access / water-affordability-new-civil-rightsmovement-united-states / (accessed on 26 March 2021).

30. Gaudin, S. Effect of Price Information on Residential Water Demand. Appl. Econ. 2006, 38, 383-393. [CrossRef]

31. Ruijs, A. Welfare and Distribution Effects of Water Pricing Policies. Environ. Resour. Econ. 2009, 43, 161-182. [CrossRef]

32. Olmstead, S.M.; Stavins, R.N. Comparing Price and Nonprice Approaches to Urban Water Conservation. Water Resour. Res. 2009, 45. [CrossRef]

33. Binet, M.-E.; Carlevaro, F.; Paul, M. Estimation of Residential Water Demand with Imperfect Price Perception. Environ. Resour. Econ. 2014, 59, 561-581. [CrossRef] 
34. Lynch, J. Officials: Flint Water Rates Could Double in Five Years. The Detroit News. 2016. Available online: https: //www.detroitnews.com/story/news/michigan/flint-water-crisis/2016/07/22/officials-flint-water-rates-double-five-years / 87461748/ (accessed on 10 April 2021).

35. Zamudio, M.; Craft, W. Water Crisis Is Growing in a Place You'd Least Expect It. NPR. 2019. Available online: https://www.npr. org/2019/02/08/691409795/a-water-crisis-is-growing-in-a-place-youd-least-expect-it (accessed on 10 April 2021).

36. Harlan, S.L.; Sarango, M.J.; Mack, E.A.; Stephens, T.A. A Survey-Based Assessment of Perceived Flood Risk in Urban Areas of the United States. Anthropocene 2019, 28, 100217. [CrossRef]

37. StataCorp. Stata Statistical Software: Release 14; StataCorp LP.: College Station, TX, USA, 2007.

38. U.S. Environmental Protection Agency (EPA). Environmental Quality Index (EQI): Overall Environmental Quality Index by County, 2006-2010. 2021. Available online: https:/ / www.epa.gov/healthresearch/environmental-quality-index-eqi (accessed on 27 December 2021).

39. U.S. Census Bureau. American Community Survey 5-Year Data (2015-2019). 2021. Available online: https:/ / www.census.gov/ data/developers / data-sets/acs-5year.html (accessed on 27 December 2021).

40. National Association of Regulatory Utility Commissioners (NARUC). Covid19 News and Resources: Map of Disconnection Moratoria. Available online: https: / / www.naruc.org/compilation-of-covid-19-news-resources/map-of-disconnection-moratoria/ (accessed on 13 March 2021).

41. Lakhani, N. Revealed: Millions of Americans Can't Afford Water as Bills Rise 80\% in a Decade. The Guardian. Available online: https:/ / www.theguardian.com/us-news/2020/jun/23/millions-of-americans-cant-afford-water-bills-rise (accessed on 7 December 2020).

42. Butts, R.; Gasteyer, S. Environmental Reviews \& Case Studies: More Cost per Drop: Water Rates, Structural Inequality, and Race in the United States-The Case of Michigan. Environ. Pract. 2011, 13, 386-395.

43. Montag, C. Water/Color: A Study of Race \& The Water Affordability Crisis; Thurgood Marshall Institute at the NAACP Legal Defense and Educational Fund, Inc. 2019. Available online: https://www.naacpldf.org/wp-content/uploads/Water_Report_ FULL_5_31_19_FINAL_OPT.pdf (accessed on 10 April 2021).

44. Beecher, J.A.; Mann, P.C.; Hegazy, Y.; Stanford, J. Revenue Effects of Water Conservation and Conservation Pricing: Issues and Practices. Columb. OH Natl. Regul. Res. Inst. 1994. Available online: https://ipu.msu.edu/wp-content/uploads/2016/12/ Beecher-Water-Conservation-Revenue-94-18-Sept-94-1.pdf (accessed on 10 April 2021).

45. Grigg, N. Affordability Programs for Water Utilities; Water Finance \& Management. 2017. Available online: https://waterfm. com/water-customer-assistance-programs-affordability / (accessed on 21 June 2021).

46. U.S. Environmental Protection Agency (EPA). Drinking Water and Wastewater Utility Customer Assistance Programs. Available online: https:/ / www.epa.gov/sites/production/files/2016-04/documents/dw-ww_utilities_cap_combined_508.pdf (accessed on 20 October 2019).

47. de França Doria, M. Factors Influencing Public Perception of Drinking Water Quality. Water Policy 2009, 12, 1-19. [CrossRef]

48. Srivastava, J.; Raghubir, P. Debiasing Using Decomposition: The Case of Memory-Based Credit Card Expense Estimates. J. Consum. Psychol. 2002, 12, 253-264. [CrossRef]

49. Kirk, E.; Lutz, C. North Carolina Water And Wastewater Rates Dashboard; Environmental Finance Center, The University of North Carolina at Chapel Hill: Chapel Hill, NC, USA, 2021. 